\title{
Impact of Information Technology on Management Control at Al Bashir Public Hospital: A Case Study of Jordan
}

\author{
Hasan Salih Suliman Al-Qudah \\ Department of Health and Hospital Management \\ Rabigh Business College, King Abdul-Aziz University \\ Kingdom of Saudi Arabia \\ E-mail: hasancare@yahoo.com; hasancare@gmail.com \\ Abdalelah Saif Aldeen Saaty \\ Dean Faculty of Rabigh Business College \\ King Abdul-Aziz University, Kingdom of Saudi Arabia \\ E-mail: assaati@gmail.com \\ Ameen Ahmad Mahboub Al-Momani \\ Department of Archaeology and Tourism, College of Arts \\ University of Hail, Kingdom of Saudia Arabia \\ E-mail: a.almomani@uoh.edu.sa; ameenmoma63@yahoo.com
}

Received: August 17, 2011

Accepted: October 11, 2011

Published: January 16, 2012

doi:10.5539/ijbm.v7n2p260

URL: http://dx.doi.org/10.5539/ijbm.v7n2p260

\begin{abstract}
Background: Information now owned by business organizations of all kinds' forms new edge of new civilized Organization as it emerges its new theme of open horizon. The importance of modern information systems had aspired all excusive to depend on this technology, management information system there for we rely on it as a" processing preparation to flourish the directors with all needed information so as to assist him in making accurate decisions and achieving Hospitals goals".

Methods and Results: The study aimed to measure role of information systems in management control at AL-Bashir Public hospital. The study included a group of $\mathbf{7 0}$ questionnaire staff administrators' questions and had distributed it randomly on a sample of population study, $\mathbf{6 1}$ have been subjected to statistical analysis questionnaire at a rate of $\mathbf{8 7 \%}$ of the population of the study. And using the program of (SPSS) package to extract results statistical analysis the members response of study sample, the researcher reached to a significant effect of the components of information systems to management control at Al Bashir hospital.

In the light of theoretical studies and statistical analysis of this study sample reached the following conclusion:

1) This research found that the level of software in hospital is high and available.

2) As of the results are concerned the physical dimension of computer sub-parts is of more important in terms of relatively level compared with other sub-dimensions of role of information systems in management control, and followed then with sub-networks of local and national levels.
\end{abstract}

The study also concluded also many recommendations as obvious that hospital directors shall execute many training courses to enable the process of control connotation among staff members, and other growth segments in the field of information systems and mere latest technology at this topic.

Keywords: Control management, Information technology, AL-Bashir hospital, Amman region 


\section{Introduction}

Most of us now are living in information age. Technology is all around us; it can be found where ever we look around. By the time we have finished writing this sentence, a new component to some form of technology has been added and is awaiting development, information now owned by business organizations of all kinds. From this emerged the importance of modern information systems and aspiring, management information system there for;" is a processing preparation to flourish the directors with the needed information so as to assist him to make accurate decisions in achieving the goals of the organization". Among the most important types of information systems is management information systems and main component element of information systems that addresses the administrative processes by using computer technology. Turning to administrative control it's considered to play an important role as its main functions can be contributed to "examine the actual performance results by comparing them with the main objectives of administrative process set by the organization".

For identifying the organization plan the control process requires that there shall be specific criteria and specified results to accomplish then comparing them with main organization objectives. (Tahi, 2005, p. 5-4)

\section{Importance of the study}

The importance of this study as it emphasizes on following:

A. The study will tray to shed light on the concept of system information and interpreting the mystics and its important application on the hospital.

B. The study will try to identify the concept of management control types and objectives, importance, and.

C. The study will identify the impact of information systems on practice that affects management control in the hospital.

D. The importance of the study at end mainly was to chick the visibility of adapting administrative control that would activate at hospital system.

\section{Study Objectives}

This study aims to answer the following:

A. Identifying levels of information technology system using at hospital its available elements on hospital information systems on the role of process administrative control system.

B. Identifying impact of using information technology systems at hospital administrative control by evaluating the overall performance effectiveness and the extent to staff and efficiency.

C. Identifying veracity of management control system used in the hospital.

D. Providing some recommendations and proposals that may contribute to improve the level of hospital information systems.

\section{Questions and Problem of study}

The study will answer the following questions:

A. what would be the impact of information systems on management control at AL Bashir hospital?

B. Did computer physical parts have an affect on levels of hospital administrative control system?

C. Does the acquired software have an affect on the effectiveness of hospital management control?

D. Is there a clear effect on basic data base information using on hospital management control system?

E. What would be the impact of local and national networks using on the efficiency of hospital management control system?

\section{Study Hypotheses}

The first major premise: "There is no statistically significant effect of information systems components on management control"

It's derived by following sub-hypotheses:

H1."There is a significant co-relationship effect between physical parts of computer and administrative control".

H2." There is a significant co-relationship effect between software and management control".

H3."There is a significant co-relationship effect between databases and administrative control".

H4."There is a significant co-relationship effect between local and international networks and administrative control". 


\section{Definitions of Key Words}

\section{A. Information systems}

Information systems are the means by which people and organizations, utilizing technologies, gather, process, store, and use disseminate information.

http://en.wikipedia.org/wiki/Information_security\#Controls

It's the processes for which information presenting to the director to assist him in making decisions and achieving organization goal.

B. Control: Authority or ability to manage or direct.

http://www.thefreedictionary.com/control

A function of the Director that its cooperation in verifying that the results conform to planned results and to identify deviations and analyzed to identify the nature and causes needed to take appropriate corrective action to remedy deviations is normal.

C. Administrative Control: Administrative controls (also called procedural controls) consist of approved written policies, procedures, standards and guidelines. Administrative controls form the framework for running the business and managing people.

http://en.wikipedia.org/wiki/Information_security\#Controls

\section{Theoretical framework and previous studies}

Ordering to effectuate the policy of the Ministry of Health, which focuses on health, is a right for all citizens and that the individual must have the highest level of health and well-being and can be reached within the available resources. Since Ministry of Health inception of delivering of health services for all citizens and distributed to meet the needs of different regions of the capital as its considered to be as of major referred hospital from all public hospital at the Kingdome counted with about 25 hospitals its note also that AL Basheer Hospital was established in 1962 and hence the of its establishment AL Basheer hospital mainly focused on providing health care for all Amman governorate since location played a vital role to all human located at all surrounded inhabitances at most crowded areas in capital Amman, it represent the following importance:

1) AL Basheer Hospital is a teaching hospital and a training referred hospital.

2) This hospital is located in the middle of city center among $\&$ between residential areas.

3) Land area on which it's constructed mounted about (12000 m2).

4) The hospital serves about one million people in province of patients referred from nearby hospitals.

5) Its associated with many educational cooperation agreements \& linked with other joint training courses between various universities and Academics institutes and colleges.

\section{Information Systems}

Information is main resources that be available to director, as rapid developments in computer technology and its application, which can be managed like any other supplier as information growing reliance usages have cure more the most complicated \& important business activities even with organization complexity or in the entity activities to managers ; at all organizational levels and in all functional areas the using output of information system can easy jobs performance, this requires to them understanding how to build an information system and how to apply and adapt them for many administrative purposes.

First: Concept of Information Systems:

Information systems can be understood through the dismantling of this term to two main elements such as "system and information".

\subsection{Definition of the system}

The simplest definitions as "a set of elements or parts that are integrated with each other and are governed by relations and mechanisms of action in certain specific range in order to achieve a specific goal". (Hassania, 1998, p. 27)

\subsection{Definition of information}

The term information in general usage refers to facts and opinions, and events of mutual and operations in public life it can be define as "a set of facts and concepts that belong to any topics, that are designed to develop and increase human knowledge" (Salmi, 2005, p. 15) 1.3 Definition of management information systems: There are no agreed definition on management information systems as some writers uses it in multiple terms, such as 
"systems of information processing" or "systems decision support" or simply "information systems".In all cases, all these expressions often indicate the aspect of information systems. The term management information system is mostly used at many common Western literatures. (Hassania, 1998, p.p 53).

Second: information systems modern approaches:

8.2.1 Introduction of computer science: It can be called entrance of information technology or technical entrance, this approach is based on the study of computer hardware and, hardware, software networks and data communications and digital media in addition to architecture of information systems and systems operation or management techniques and information resources based on the Internet.

8.2.2 The entrance of this management science: is so-called management entrance which deals with field from administrative framework perspective of regulatory information systems based on analysis of relationship between information systems and business, particularly the study indicated requirements of environment information systems in the areas of core business, and strives to achieve realignment strategy, and objectives and functional systems information.

Strategy and business objectives, is also momentous in this approach for studying the impact of mutual relations between information system and business organizations and through its application of programs and projects, total quality management, and business re-engineering, knowledge management and business intelligence. Etc (Yassin, 2009, p. 34-36).

Third: Types of information systems: A. Information systems to supported by senior management (ESS): The related information systems refers to strategic level, or things which are used: like sales forecasting for next five years, operation planning developments for the next five years, budgeting forecasting requirements for the next five years, or planning profit, manpower planning. B. Management information systems (MIS): The used of information systems levels at administrative level may including: sales management, stock control, annual budget, the analysis of investment in working capital.C. Information Systems Decision Support (DSS): The second type used on the level of information systems at the administrative level, and includes: an analysis of areas of sales, production scheduling, cost analysis, price analysis and profitability, reduce costs. (Almagrbhi, 2005, p. 98-109).

Forth: Elements of management information systems. A. Data Input requirements for feedings of system are collected from internal environment, (the organization's activities) and through feedback of external environment, (political factors, economic, social, cultural...etc. B. Treatment processes creation of data entered into system and filtered, indexed (classified and arranged), then reporting information to information storage retrieval and updating. C. Information generated Output after data processing system. (Tai, 2005, p. 26-27).

Fifth: Characteristics and main features of management information systems: A. The MIS is characterized by information requested as known as, "a stable system", that once was supposed to correct the system to deal with certain kinds of problems. B. Provide support capacity of the structure and the levels of management control. C. Providing public reports regards to processes that occur day after day. (Almagrebhi, 2005, p. 105), (Salmi, 2005, p. 67).

Sixth: Components of management information systems. A. Devices: it's assumed that today in any computer system to be composed especial computers shall become available at affordable lowest prices for most organizations, the computer system can be a personal computer or a medium-sized or large or diverse network of computers. B. Software: systems that are running hardware, data, information and knowledge, determine operations performed by the devices. C. Database: database storage or containers that contain data describe all processes and events at the organization, with all its important activities details in all forms of files must be accessible. (Hassania, 1998, p. 56-59).

Benefits of management information systems: 1. Providing information to all various administrative levels as needed for purpose of exercising functions at deferent aspects like planning, organization and control. 2. Assess all organization activities and be able to evaluation its results in order to correct deviations. 3. Help to predict the future organization prospects in order to take necessary precautions in case of a defect in achieving objectives. 4 . Save data and historical information necessary as the foundation in its work. (Salmi, 2005, p. 64-65). Second :Control We can not imagine a system of control was as important as of dealing to replace sense of individual's personal responsibility stemming from the depths of his conscience is another proof of Allah at the holy Quraan said; "God commands you to return trusts to their owners." Holy Prophet Mohammad peace be upon him specify that; "God loves the one who work on shall do proficiently", work is the secretariat to individual's sense of duty and a polite way to his conscience and to his commitment to mastery of his work and play as it should be on this basis for exercising of those Secretariat to their owners (employers), because some 
workers ignore this aspect, it has become to be an effective system of control, especially if the reason for the negative standard deviation is workers neglecting or lacking dedication to work.(Dahan et al, 2005, p. 252)

\subsection{Concept of Control}

The leader's administrator's main tasks are to make sure that organization administrative direction of work is directed towards achieving the organization goals in accordance with plans set. It confront any possibility of deviation from certain criterion and so they are functions accordingly by ongoing critical to ensure discipline and preventing administrative deviation within rules and procedures prescribed by law. (El Serafy, 2006, p. 5)

(The word control is derived from French expression contre -role, (A Role Opposite), it confirmed the authenticity and sincerity of original role, and it conformed to a reality, as it tends mostly by economic researchers the using of the term control to benefit of meaning of audit and control.(Alsabah, 1997, p. 13)

\subsection{Importance \& Oversight}

A. Control tries to achieve effective regulatory system, alignment between individual goals and organization objectives as a whole.

B. Control detect any deviation occurs or is expected to occur on the plan set as soon as possible and determine the reasons for the deviation. C. Accounting tool in determining the profits and losses and show the administration in each period of the actual status and the general trend of business development and achievement. (Alzobi, 1995, p. 251).

\subsection{Objectives of Administrative Control}

A. It identifies problems and obstacles to flow by operational work with a view to overcoming them. B. It ensures of the performance technical operations in accordance with stipulated principles and then evaluating the crooked one. C. It ensures the working of government services are provided to all. D. It evaluates managers to ensure efficiency at all levels and good behavior. (Abbass, A, 1995).

\subsection{Areas of administrative control}

A. In field of production: the use of management control is to ensure the quality and quantity of production ascertaining no waste of materials on other firm's inputs. B. In the area of procurement: ensure the safety and quality of procurement and compliance with the specifications requirements. C. In field of storage: controls can make movements of inventory in terms of quantity received and issued remaining balance and safety stock, by protecting of risks or any other damage.

Properties of Control: A. It does not consider authority as a" stand-alone" or considering it as branch of other units or branches of administrative process. B. It is not restricted to a particular stage at all levels of administrative activities, control intervention as envisioned, organized with conditions of proposed plans and policies. C. As it presents at all administrative levels, to see an impact in the work of all managers and in the resolutions of the shareholders. (El Serafy, 2006, p. 15-30)

\subsection{Why uses control}

A. It discovers deviation from the standard and then corrected after identifying the actual causes. B. It uses results as feedback to modify plans and develop them to be more realistic and more accurate. C. Assessment of organization efficiency in general to judge the success of the methods of management and policy.

\subsection{Conditions \& Formation of Effective Control System}

A. It presence a balanced and consistent with achieving the specific objectives of the organization. B. It presence organization clearly by defining the powers and responsibilities of administrative staff in all form of power. C. In administrative unit it concerned with the working of Accounting and Statistics experts, this unit will help compilation of information and processing for the control process. (El Serafy, 2006, p. 15-30)

\subsection{Characteristics of effective Control System:}

A - The control system as simple as possible, free from the complexity unnecessary, and commensurate with the needs and capacities of persons engaged in the process of censorship. B. Flexibility, where there must be flexibility in the regulatory system and the ability to adapt to the latest changes to the organization such as a change of plans and goals. C. Easy to understand, must be a control system simple and clear so can be understood and applied. D. Control system to be accurate, the information must be accurate to be useful and helpful. E. The regulatory system is renewed and kept up with the advanced scientific theories and suitable for practical application. (El Serafy, 2006, p. 15-30)

\section{Previous studies}

A study made by Gita macel\& others,(2009),entitled," The Development of the management control system in Romania ", about European Commission's recommendation, and for the harmonization and compatibility of the 
internal public financial control system of Romania with the European Union's system, established a structures within the Ministry of Economy and Finances: - Central Harmonization Unit for Public Internal Audit CHUPIA, in 2003 ,Central Harmonization Unit of Financial Management and Control Systems - CHUFMCS, in 2005Thus, Romania has set up two central harmonization units, one for the organization and implementation of internal audit - CHUPIA, and the other for the reorganization and implementation of the internal control and financial management system - CHUFMCS. The main attribution of CHUFMCS it is represented by the development of the own internal control and management systems within the public entities. As such, Order of the ministry of public finances no. 946/2005 approving the Internal Control Code, comprising 25 internal control standards structured on the five principles of COSO internal control Model, which must be, gradually, implemented in Romania for the reorganization of the existing internal control system \&concluded that the process for implementing the managerial control system in Romania will be monitored by CHUPIA from the Ministry of Economy and Finances, once at every 5 years and by the Court of Accounts, every year, with the occasions of the missions unfolded by this institution and will represent an external evaluation for public entities regarding the evaluation of the steps taken in implementing the managerial control system.

Yet another study accomplished by Perkinsm,Bart (2005), "Management controls: A Lost Art". This article comments on the decline in the use of the basic management controls which is required to run an effective information technology (IT) organization. Many companies have lost touch with the fundamentals of IT management. As a result, these companies are often unable to perform basic IT functions, such as building coherent business cases, assessing projects risk, and developing accurate capacity plans. The author provides methods of upgrading management control of companies.

Sendroiu, Cleopatra Roman, Aureliana Geta, (2009), at there article" Management control internal control: for a performance organization." The internal control focus on the whole system of financial and non-financial controls, the organizational structures, methodologies, procedures, including the internal audit, set by the management in accordance with its objectives, meant to help them in managing the audited entity in an economic, effective and efficient manner. The management control should stimulate the permanent development of the control instruments and to constantly contribute to the improvement of the organization performances, while other procedures and tools which are part of the control mechanisms occur during the financial year as one event only, or are of a periodical nature.

Domnisioru, Sorin \&others, (2009), pointed out at there work "Internal audit and management control -contiguous levers for modern organization management" Spoke about the economic crisis has forced theoreticians and practitioners to reflect on the ways to overcome the difficult situations faced by most organizations as well as on old problems which the crisis has revealed Organizations must have mechanisms in order to detect them. To the achievement of such an objective there can contribute, among other elements the management control and the internal audit they brought to the fore the issue of management control in relation to internal audit in order to show exactly what each of them should represent. Designed in the spirit evoked by us in this paper, the duet may constitute a true resource designed to provide a proactive and creative management, and its implementation in the position and the role for which the two components were created by the international organizational experience.

Other deferent study don by Erbschloe, Michael, (2009),"Information Systems auditing". As this article examines the purposes of information systems (IS) auditing, the methods that are used to perform IS audits, and the types of findings that IS auditors include in audit reports. The article explains the five different types of audits performed on information systems: Development, application, computer operations, management, and technology. Control Objectives for Information and related Technology (COBIT) are explained and the use of COBIT in the audit process is examined. To illustrate the types of findings that IS auditors present to audit sponsors, the results of a General Accountability Office (GAO) audit of multiple U.S. Government agencies are presented. The development and dissemination of the IS Auditing Standards by Information Systems Audit and Control Association (ISACA) are reviewed along with the IS auditor's code of ethics.

Lainhart.IV. \& John W, at there study, (2000)," COBIT: A Methodology for Managing and Controlling Information and Information Technology Risks and Vulnerabilities".

contributed about the methodology for managing and controlling information and Information Technology risks and vulnerabilities addresses the need for management and control of information and related information technology. It recognizes that effective management of information and related IT is critically important to the success and survival of organizations. In this global information society where information travels through cyberspace without the constraints of time, distance, and speed this criticality arises from the increasing dependence on information and the systems that deliver this information, increasing vulnerabilities and a wide spectrum of threats, such as cyber threats and information warfare, scale and cost of the current and future 
investments in information and information systems, and potential for technologies to dramatically change organizations and business practices, create new opportunities, and reduce costs.

Gamze Bal, \& Canan Davidson completed there work on, (2011),"Use of Information Technologies in University Hospitals in Different Variables for Investigation". The objective of this current study was to examine whether university hospital administrators' education level and age as well as the number of beds in the hospital have any impact on the information technologies that are currently in use. The finding of this study reveals that the most widely used information system in the health-care industry includes automation software, office automation systems, and web design tools. However, it is concluded that some types of the information systems, including internet, intranet, extranet, functional information systems, management information systems, expert systems, decision support systems, and electronic data exchange systems, are underutilized as compared to automation software, office automation systems, and web design tools. It is also pointed out that health-care administrators' education level and age as well as the number of beds in the hospitals do not have an impact on the information technologies used in the hospitals.

As of Murray, James, (2006),"Configuration controls help IT to prosper IT". The deployment of change and configuration management controls is the single most important factor determining the performance of an IT department. That is the conclusion of a recent study, the article discusses a research by the IT Process Institute which focuses on the importance of the deployment of change and configuration management controls in the performance of an information technology department. The study assessed the performance of almost 100 large IT departments and found that the top performers had the widest adoption of change and configuration management controls and systems.

Jamal, Aziz\& others, (2009)," The impact of health information technology on the quality of medical and health care: a systematic review". The aim of this study was to systematically review the published evidence of the impact of health information technology (HIT) or health information systems (HIS) on the quality of healthcare, focusing on clinicians' adherence to evidence-based guidelines and the corresponding impact this had on patient clinical outcomes. The review covered the use of health information technologies and systems in both medical care (i.e. clinical and surgical) and other areas such as allied health and preventive services. Studies were included in the review if they examined the impact of Electronic Health Record (EHR), Computerized Provider Order-Entry (CPOE), or Decision Support System (DS); and if the primary outcomes of the studies were focused on the level of compliance with evidence-based guidelines among clinicians. Measurements considered relevant to the review were either of changes in clinical processes resulting from a change of the providers' behavior, or of specific c patient outcomes that demonstrated the effectiveness of a particular treatment given by providers. Of 23 studies included in the current review, 17 assessed the impact of HIT/HIS on health care practitioners' performance. A positive improvement, in relation to their compliance with evidence-based guidelines, was seen in 14 studies that included an assessment of patient outcome.

Spats, Joanne, (2009)," Information Technology Implementation in a Rural Hospital: A Cautionary Tale". An increasing number of hospitals are implementing electronic medical records and other information technology (IT), and national policy is focused on fostering expansion of these systems. In September 2004, a 100-bed acute care hospital in a rural community was awarded a grant to implement and evaluate an integrated hospital IT system. The evaluation used qualitative and quantitative methods, including examining data on patient outcomes, conducting surveys of staff, and interviewing leaders and staff about the implementation process. In the end, the hospital suffered a number of setbacks during the implementation that could provide lessons to other hospitals. The hospital was hindered by a lack of clinical leadership, staff skepticism, turnover in the executive team, an overly aggressive schedule, and a vendor whose products were not ready on time. The IT implementation was associated with a large increase in patient care errors, including medication errors, procedure errors, and patient falls. These patient errors might have been averted if the launch of the IT system had been better planned and implemented.

Amarasingham, Ruben and others, (2008)," Hospital characteristics associated with highly automated and usable clinical information systems in Texas, United States". This was a cross-sectional survey of 125 urban hospitals in Texas, United States using the Clinical Information Technology Assessment Tool (CITAT), which measures a hospital's level of automation based on physician interactions with the information system. Physician responses were used to calculate a series of CITAT scores: automation and usability scores, four automation sub-domain scores, and an overall clinical information technology (CIT) score. A multivariable regression analysis was used to examine the relation between hospital characteristics and CITAT scores Results: We received a sufficient number of physician responses at 69 hospitals (55\% response rate). Teaching hospitals, hospitals with higher IT operating expenses ( $>\$ 1$ million annually), IT capital expenses $(>\$ 75,000$ annually) and hospitals with larger IT staff ( $\geq 10$ full-time staff) had higher automation scores than hospitals that did not meet these criteria $(p<0.05$ in 
all cases).

Fortmeyer, Russell, (2007),"The New Age of High-Tech Hospitals". This article focused on the convergence of information technology (IT) systems of Sidra Medical and Research Center, an American hospital to be constructed in Doha, Qatar. Architectural firms Ellerbe Becket and Pelli Clarke Pelli are commissioned for the project. The health-care technology of the hospital will feature the convergence of all applications in a single digital conduit. Under convergence, health-care architecture will centralize all digital systems in data centers and provide smaller closets for managing wireless devices.

Gamze Bal \& others, (2010)," Become a Meaningful User of Health IT". At this paper it reports on topics which were discussed at a round table of medical experts which was held on September 30, 2010 in Chicago, Illinois. Topics included the use of information technology in hospitals and health care reform legislation which was passed in the U.S. in 2010. The event featured several hospital executives and information technology specialists including Pamela McNutt of Methodist Health System, David Muntz from Baylor Health Care System and Jim Veline from Avera Health.

Brooks, Robber, \& others,(2005)," Patient Safety-Related Information Technology Utilization in Urban and Rural Hospitals". The researchers has linked certain information technology applications to reduction of medical errors and improved patient outcomes. The purpose of this study was to assess both the use of patient safety-related information technologies (PSIT) in urban and rural hospitals, as well as the organizational factors which may be linked to overall PSIT adoption. Florida's 199 acute care hospitals (170 urban; 29 rural) were surveyed regarding their utilization of PSIT. Of the 10 technologies studied, rural hospitals averaged $30 \%$ utilization compared to $48 \%$ for urban hospitals. The findings are valuable for those interested in the current status of hospital PSIT and set the stage for further studies relating these applications to clinical outcomes in urban and rural.

\section{Method and Procedures}

This chapter describes the method and procedures to achieve the objectives of the study, and includes a description of the research methodology, and determine the study population and sample, how to prepare and develop a tool of study and methods to ensure the stability of the tool and procedures for implementation, and includes the identification of variables to consider and ways to address the data statistically to draw conclusions of the study.

\section{Curriculum}

Aim of the current study to measure the impact of information technology on management control, the researcher followed the descriptive analytical method, which relies on the study of reality or phenomenon, and based on field surveys to obtain data from original sources by relying on the identification has been designed according to the steps of scientific adopted in this regard and data processing and analyzed statistically to gain access to test research hypotheses and answer his questions.

\section{Study population}

With regard to the community in this research study, it has included individuals working in the field of Information technology and management control in hospitals.

The study sample the study sample included (61) members of staff in a hospital in the AL- Basheer public Hospital.

\section{Demographic variables for members of the study sample}

Included the demographic variables of the study are: gender, educational qualification, number of years practical experience and age sigma. Table (1) shows the distribution of respondents by demographic variables and distribution of study sample according to demographic variables as following:

Table (1) has shown the sample study in terms of Gender was distributed to (33) as (54.1\%) in male\& (28) in female by $(45.9 \%)$. In terms of qualification, the largest number of the study sample shows bachelor's degree holders as the total number of (40) as $(65.6 \%)$, while the lower class in terms of qualification of the study share are of "Higher School and below", where the numbered (4) and by (6.6\%).

As for the variable demographic number of years of practical experience, the majority of respondents of (53) individuals with experience are "less than 5 years, "have formed a proportion of (86.9\%) followed by (6) of respondents from those who have experience (50-10 years) and their percentage $(9.8 \%)$, and that there is one individual categories for each of the other two categories of the variable "number of years of practical experience." 


\section{Study tool and sources for obtaining information}

In Order to achieve the study objective, it has relied on each of the following sources of information: 1. Information on theoretical side of research, like studies, articles, theses, books, scientific and Arab and foreign specialized subject of study. 2. Resolution for providing data to study a questionnaire were designed after taking opinions of a group of researchers in the field of study, which aimed to obtain primary data to complete the study practical side in terms of addressing study questions or for testing hypotheses, and including a resolution of two Parts namely: The first part is the section on demographic variables of the study sample through (4) are the variables (sex, educational qualification, number of practical years of experience and age).

The second part will included study variables of two major dimensions; firstly information technology and that will be measured in B (4) the dimensions of the sub: parts of the material of computer, software, databases and networks of local, national, secondly the administrative control that's included by (36) paragraph which was distributed as follows:

Information Technology: will including (19), paragraph and sub-dimensional distributed to the following:

1. Physical parts, computer and included (3) paragraphs.

2. Software: included (6) paragraphs.

3. Databases: included (3) paragraphs.

4. Local and national networks: included (7) paragraphs.

5. Administrative control: included (17) paragraph.

Despite the diversity of methods of measurement, the current study followed a method of measurement based on a scale of Likert, and paragraphs of different dimensions in terms of how alternatives to answer each paragraph of the (1-5) according to the following:

\section{Stability Tool}

The study was calculated coefficient of Cronbach alpha (Cronbach Alpha) to ensure stability of measuring tool and that questionnaire was measured on the basic of factors to measured and for verification its credibility, due to nature of coefficient of Cronbach alpha which measures the internal consistency of clauses of measurement, this means that correlation and coherence between paragraphs scale and thus give him a good estimate for persistence, despite that the rules of measurement in the value to be obtained from laboratory wasn't specific, but access to (Alpha $\geq 0.6$ ) in practice of Management Science and humanity in general is acceptable (Sekaran, 2003). For this study (Combat Alpha $=0.919)$.

\section{Statistical Treatments}

In order to reach the indicators that support the objectives of the study, by testing hypotheses, it has been used for many statistical treatments described below through the use of the program (SPSS 15), and the statistical methods used in this study include:

* Cronbach alpha coefficient (Cronbach Alpha) to make sure that the degree of stability of the measure used.

* Frequency distributions and percentages and standard averages deviations to the study answer questions and finding out relatively importance at each paragraph the dimensions of the study.

- Simple regression analyses for measuring impacts of one variable independent on other variable dependent.

* F-test and moral regression test, a simple t-test for significance of regression coefficients and simple.

* Coefficient of determination to illustrate of independent variable importance in explaining values changes of variable dependent.

* Descriptive statistical indicators for the study variables in light of the answers members of the study sample.

The deviations standard of each separately dimensions would include all variables by ranking them under paragraph one-dimensional. As follows:

First, physical parts of a computer: Table (2) shows the standards describe the physical dimension of the sub-parts of a computer and paragraphs of the measurement of its own, including the mean and standard deviation of the description and the rank and relative importance.

Insert Table 2 here

The illustration results of Table (2) as it measured parts of physical computer high in terms of relative importance, (4.0601) standard deviation (0.5693), which indicates as made at paragraph," The hospital has hardware and software that facilitate operations of beneficiary within and outside" as it ranks first among paragraphs of this scale as central arithmetic attained (4.2131) the standard deviation was (0.70981) as it was 
high relatively importance, the paragraph related to," There is widespread use of computers in the hospital, especially in the field of management "as it ranked second among the paragraphs of the scale, with an average arithmetic of (4.0656) and standard deviation (0.85379) and the relative importance of high, while ranked third paragraph," The hospital have the necessary equipment of modernization and development to carry out data processing," the central arithmetic was (3.9016) and the standard deviation was (0.92565) yet it was high relatively importance as well.

Second; Software: Table (3) shows the dimension standards describe the level of sub-paragraphs of software and measurement of its own, including the mean and standard deviation of the description and the rank and relative importance as elucidate below:

\section{Insert Table 3 here}

The results of Table (3) indicates that the scale dimension assess of "software" is relatively high and importance, it has reaches up to (3.9536)and standard deviation is (0.57906), yet to clarify it extensively as explained has been made at following paragraph" It Can be dealt easily with hospital software and hardware, "it prove to be true that between paragraphs of this scale at central arithmetic reached to (4.0328) but standard deviation was (0.89382) as it was ascertain and highly relatively importance, while the paragraph imply on "The use of hospital information systems has its increase significantly on accuracy "came in second among other paragraphs of the scale, with an average of the arithmetic (4.0164) and standard deviation (0.99149) and was relatively importance high, came in paragraph "7" came in last in central arithmetic (3.8361) and a standard deviation signify (0.95185) this is relatively importance high also.

Third, rules of information:

Table-(5) shows standards describe the level of sub-dimension about "rules of information and measurement of its own ", the mean and standard deviation of the description and the rank and relative important it include means and standard deviation of this description and ranks of it is relatively important.

\section{Insert Table 4 here}

The results of Table (4) databases indicates that the scale is high and relatively importance, the arithmetic mean prove to imply to reach (3.9126) but standard deviation signify (0.68827), the relation ship made at paragraph "data is entered accurately while doing the work doing the hospital work " ranks first among the paragraphs this measure of central arithmetic (3.9672) as standard deviation reveals to (1.03227) and is relatively importance state high, as was paragraph " Hospital system maintains with developing information systems to keep up with current development in information technology " came in second among the paragraphs of the scale, with an average arithmetic of (3.9508) while standard deviation was $(0.84511)$ yet it was highly relative importance. While paragraph that set forth "Hospital deals with data resources is working to serve on a data service end-use" ranked last in central arithmetic (3.8197) the standard deviation is $(0.90385)$ as it proves to be higher relatively importance.

Fourth: Local and National Networks: Table (5) shows the standards describe the level of the sub-dimension "of local and national networks" and paragraphs of the measurement of its own, including the mean and standard deviation of the description and the rank and relative importance it describes and assess level of local and national networks:

\section{Insert Table 5 here}

Its noted her from results of table (5) that the scale of local networks and national in terms is highly relatively importance, this was meant to that the arithmetic means at (4.0047) and the standard deviation was $(0.63405)$, meanwhile it has made by paragraph, "provide the internet for staff and administrative leaders in the organization many benefits in the area of jurisdiction "stands at first degree from the paragraphs scale and mark an entry at the central arithmetic to total of (4.3770) whilst the standard deviation reached to (0.81984) as it state as high relatively importance, while paragraph mentioned as" gives me the Internet to identify the latest developments in the field of jurisdiction," came in second among paragraphs scale, with an average of arithmetic cited to (4.1639) while the standard deviation perceived to (1.08290) as it becomes distinct as highly relatively importance, while the following paragraph clarify "the organization uses the latest communications media and networks to transfer data both within and outside the Organization "ranked last in central arithmetic at a point of (3.7869) while the standard deviation shown at rate of (1.08189) indicating as high relatively importance.

V: Management Control: Table (6) shows the standards describe the level of management control and measurement paragraphs of its own, including the mean and standard deviation of the description and the rank and relative important.

Insert Table 6 here 
The results of Table (6) shows level scale of management control in terms was high relatively importance ,the arithmetic means appears to reach to (3.8370)whilst the standard deviation was $(0.54618)$ meanwhile the paragraph that revealed as " It reflects the regulatory process of hospital working on factual information on working progress" the relationship between previous paragraphs of this scale in central arithmetic reached to (4.0984) the standard deviation was (0.83076) and the relative importance is high, as was paragraph" Control Contributes to the regulatory hospital process to detect deviations efficiently and effectively," came in second among the paragraphs of the scale, with an average arithmetic (4.0492) and standard deviation (1.05556) and the relative importance is high, as was the paragraph of the hospital to conduct training courses for those in charge at process control, "last but not least the last in central arithmetic ranked at (3.8370) meanwhile its standard deviation maintained at rate of $(0.54618)$ has medium relatively importance.

\section{Results and Interpretation}

While dealing with this paragraph the main study hypothesis testing and sub-hypotheses derived from concentrated to accept or reject the study hypotheses, through using of simple regression analysis \& multiple regression based on statistical tests as follows:

\section{Insert Table 7 here}

Simple regression analysis of the impact of each independent variable (Sub-D) to find management control

Regarding to hypothesis analysis model of the Sub:

1) The first hypotheses, represent relationship between independent variable imply to computer main parts with dependent variable of management control in terms of value indicate $(F=39.269)$, when compared with value $(\mathrm{sig}=0.000<0.05)$, as that form explains almost rate of $(40.0 \%=\mathrm{R} 2)$ of other differences values of dependent variable, has impact on independent variable and on dependent variable with value of $(0.606=\beta)$ is also significant on the account facts refers to value to $(t=6.266)$, so we rejects the first sub-hypothesis, and accept the alternative hypothesis, which states: The results of second sub-hypothesis" there is a statistically significant effect of physical parts of the computer on a management control."

2) The second hypotheses, represent relationship between independent variable imply on software with dependent variable of management control in terms of value $(\mathrm{F}=54.759)$, when compared value (sig $=0.000$ $<0.05)$, the model explains almost at rate of $(48.1 \%=\mathrm{R} 2)$ of differences values of variable of impact of independent variable on dependent variable value of $(0.645=\beta)$ is also significant with the fact refers to value of $(\mathrm{t}=7.4)$, so we rejects the hypothesis the second tier, and accept alternative hypothesis, which states: The results of the third sub-hypothesis" there is a statistically significant impact of software on the management control."

3) The third hypothesis, represent the relationship between independent variable data bases and variable dependent of management control in terms of value $(\mathrm{F}=28.011)$, compared with value of $(\mathrm{sig}=0.000<0.05)$, the model explains almost $(32.2 \%=\mathrm{R} 2)$ of differences in values of dependent variable, the impact of independent variable on dependent variable value of $(0.450=\beta)$ is also significant for the fact that value of $(t=$ 5.293), so we reject the third sub-hypothesis, and accept the alternative hypothesis, which states: The results of the fourth sub-hypothesis "there is a statistically significant effect of the rules of information on management control." 4. The Fourth hypothesis, represent the relationship between independent variable imply on networks of local, national, and variable dependent of management control in terms of value $(\mathrm{F}=54.886)$, when compared with value $(\mathrm{sig}=0.000<0.05)$, the model explains almost $(48.2 \%=\mathrm{R} 2)$ of differences dependent values variable, has its independent variable impact on variable dependent at rate of $(0.598=\beta)$ is also significant for the value facts at $(\mathrm{t}=7.408)$, thus we rejects the fourth sub-hypothesis, and accept the alternative hypothesis, which states: There is a statistically significant "impact of the networks of local and national administrative oversight." To investigate the validity of first major hypothesis, we used multiple regression method of gradual decline; the following table (8) analysis shows results:

\section{Insert Table 8 here}

The results of this table (8) pointed out the existence of (3) model used, the first model was introducing of independent variable most correlation variable of (management control) as a variable of local and national network. In model II" software" were added to variable of variable to first model, it has improved the value of coefficient determination at (R2), aftermath it indicates addition variable "portions of computer material ", the value interpreted by the independent variables of the three accounted mounted at rate of $(63.0 \%)$ of differences in management control, while excluded of dimension (sub information standards) of multiple regression model caused to weakness of which explain by differences of management control compared to three dimensions in multiple regression model. In other hand, we noted no change at three coefficients independent variables signal the three models, which quote as an example impression in other words there is no problem of multi-linear 
(no high correlation between them), and this one of the reasons that led to the exclusion sub-databases dimension. In addition the value $(\mathrm{F}=32.352)$ refers to the statistical significance of the moral of the model III and to each of the independent variables of three affect significantly on administrative control (values of $T$ when compared with significance level), most influential dimension of the sub-"Networks of Locally and Nationally" where was this effect (0.316), and model III explains (63\%) differences in management control values.

\section{Conclusion}

In the light of theoretical studies and statistical analysis of this study sample reached the following conclusion: 1 . The research found that the level of software in the hospital is high and available. 2. As of the results are concerned the physical dimension of computer sub-parts is of more important in terms of relatively level compared with other sub-dimensions of role of information systems in management control, and followed then with sub-networks of local and national levels. 3. The results revealed a statistical significant effect in respect of physical parts of computer on a management control in return to use computer mechanism in the organization in general \& in field of business management in particular. 4. The results showed statistical significance effect compared with management control usages of software by hospital systems and the aggregate of different software which at most fit with the different operations. 5. The results indicated statistically significant effect on database with administrative control for the fact that by using of information technology mission hospital seeks to achieve them. 18. Recommendations: Based on the conclusions reached, we get out of this study group of following recommendations: 1 . Attention shall be given in securing a communications network in an effective manner and efficient to facilitate the exchange of information and data with each other and increase the number of computers of different types more than the current (computer, cameras, scanners, printers ....), attention shall be given also to development of latest software and to increasing levels of effectiveness and efficiency at the hospital premises. 2. Execution of many training courses to enable the process of control processing among staff members, and other developments in the field of information systems and mere latest technology at this topic. 3. Providing internet services to all employees by promoting it at the hospital activities since it will help them to update the programs that in use automatically, and it would increase the staff culture refinement, and help them to follow up developments in their field by focusing on latest technical efficiency adapted by control efficient process. 4 . To be Chief Justice in the regulatory process and inclusiveness, and is based on the Merits. 5. Diversification of control methods used shall take in consideration the change from one time period to another, so that employees at all times willing to censor their work, which might mean their commitment to their jobs and complete to the fullest.

\section{References}

Abass, Ali. (1995). Control Management On business assets at some corporate financial corporation. Dare Alethraa for publication, Amman-Jordan.

Almagrhbi, Abdulfatah. (2005). Management information system-Functional Approach. Alharithy Publication office, Egypt, p.p. 98-109.

Alsabah, Abdulrahman. (1997). Principle of Control. Dar Zahran for Publication, Amman, Jordan. p.p.13.

Alzobi, Faize. (1997). Control Management at Administrative Organization. Mouta University Publication, Jordan.

Amarasingham, Ruben., Diener-West, Marie., Plantinga, Luara \& others. (2008). Hospital characteristics associated with highly automated and usable clinical information systems in Texas, United States. BMC Medical Informatics \& Decision Making, Vol. 8 Issue 1, Special section p1-11.

Brooks, Rober, Menachmi. Nir., \& Burk, Darrel. (2005). Patient Safety-Related Information Technology Utilization in Urban and Rural Hospitals. Journal of Medical Systems, Vol 29 Issue 2, p103-109. http://dx.doi.org/10.1007/s10916-005-2999-1

Dahan Omaimah, Salem Alshekh, Ramadan Fooad \& Ziad Makhamreh. (2005). Modern Administration Consepets. Jordan Book Center, Amman-Jordan, P.p. 252.

El Serafy, Mohd. (2006). Control Innovation. Alhawras corporation for publication, Alexandria, Egypt. P. p. 15-30.

El Serafy, mohd. (2006). Ingenious Control. International Alhawras for Publication \& Distribution, Alexandria, Egypt, p.p. 5 .

Erbschloe, Michael. (2009). Information Systems Auditing. Information Systems Auditing -Research Starters Business, p1-7,7p.

Formeyer, Russel. (2007). The New Age of High-Tech Hospitals. Architectural, Vol. 195 Issue 9, p151-159. 
Gait Marcel. Ion, Notu, Popescue, Marine. (2010). The Development of the management control system in Romania. Metalurgia International, Special Issue 1, p21-25.

Gamez Bal \& Canan Davidson. (2011). Use of Information Technologies in University Hospitals in Different Variables for Investigation. Journal of Social Sciences, Vol. 10 Issue 2, p749-759.

Gamze Bal, Canan \& Akgrci, Tahir. (2010). Become a Meaningful User of Health IT. H\&HN: Hospitals \& Health Networks, Vol. 84 Issue 12, p47-57, 11p, 19.

Hannah, Stanley. A. (1995). A comparison of Software Methodologies in the Development of A serials Control System. India University Dissertation Abstract International, Vol. 55, No.8.

Hassania, Saleem. (1998). Principle of Management Information System. Alrwauaq Publication Center. Amman-Jordan, p.p. 27.

Hassania, Saleem. (1998). Principle of Management Information System. Alrwauaq Publication Center, Amman-Jordan, P.p. 56-59.

El Serafy, mohd. (2006). Ingenious Control: International Alhawras for Publication \& Distribution. Alexandria, Egypt, p. 15-30.

Jamal, Aziz, Mckenzie, Kristan \& Clerk, Michele. (2009). The impact of health information technology on the quality of medical and health care: a systematic review. Health Information Management Journal, Vol. 38 Issue 3, p26-37, 12p.

Lainhart. IV., \& John W. (2000). COBIT: A Methodology for Managing and Controlling Information and Information Technology Risks and Vulnerabilities. Journal of Information Systems, Vol. 14 Issue 1, p21. http://dx.doi.org/10.2308/jis.2000.14.s-1.21

Murry, James. (2006). Configuration controls help IT to prosper IT Week staff The deployment of change and configuration management controls is the single most important factor determining the performance of an IT department. IT Week, Vol. 9 Issue 41, p9-9.

Perkinsm, Bart. (2005). Management controls: A Lost Art. Computerworld, Vol. 39, Issue 19, p36-36.

Salmi, Alaa. (2005). Basic Management information System. Dar Almanaheg of Publication and Distribution Center, Amman-Jordan, p.p. 67.

Salmi, Alaa. (2005). Basics of Management Information System. Dar Almanaheg Publication Center. Amman-Jordan, p.p.15.

Sendroiu, Cleopatra \& Roman, Geta. (2009). Management control internal control: for a performance organization. Metalurgia International, Vol. 14, p129-132.

Sorin \&others. (2009). Pointed out at there work: Internal audit and management control -contiguous levers for modern organization management. Metalurgia International, Vol.15, p89-94.

Spetz, Joaane \& Keane, Dennis. (2009). Information technology Implementation in a Rural Hospital. J Healthc Manag., Vol. 54 Issue 5, p337-348.

Tahi mohd. (2005). Approach of Management Information System. Dare Wael for Books Publication. Amman-Jordan, P.p. 5-4.

Tahi, mohd. (2005). Approach of Management Information System. Dare Wael for Books Publication, Amman-Jordan, P.p. 26-27.

Yassin, Saeed. (2009). Management information system. Dar Alyazori for distribution \&Publication center, Amman-Jordan, p.p.34-36. 
Table 1. Distribution of study sample according to demographic variables (Variable Category Number repetition percentage)

\begin{tabular}{|c|c|c|c|c|}
\hline Percentage & Repetition & Gender & Variable & Number \\
\hline 54.1 & 33 & Male & \multirow{2}{*}{ Category } & \multirow{2}{*}{1} \\
\hline 45.9 & 28 & Female & & \\
\hline 100.00 & 61 & \multicolumn{3}{|c|}{ Total } \\
\hline 6.6 & 4 & High School & \multirow{4}{*}{ Qualification } & \multirow{4}{*}{2} \\
\hline 18 & 11 & Diploma & & \\
\hline 65.6 & 40 & Bachelor & & \\
\hline 9.8 & 6 & Higher Studies & & \\
\hline 100.00 & 61 & \multicolumn{3}{|c|}{ Total } \\
\hline 86.9 & 53 & Less than 5 Years & \multirow{4}{*}{$\begin{array}{l}\text { Number of } \\
\text { years of } \\
\text { experience }\end{array}$} & \multirow{4}{*}{3} \\
\hline 9.8 & 6 & $10-5$ Yeas & & \\
\hline 1.6 & 1 & $\mathbf{1 5}-11$ Years & & \\
\hline 1.6 & 1 & 16 Years or More & & \\
\hline 100.00 & 61 & \multicolumn{3}{|c|}{ Total } \\
\hline 83.6 & 51 & Less than $\mathbf{2 5}$ & \multirow{4}{*}{ Age } & \multirow{4}{*}{4} \\
\hline 11.5 & 7 & 25-35 Years & & \\
\hline 3.3 & 2 & 45-36 Years & & \\
\hline 1.6 & 1 & 46 or More & & \\
\hline 100.00 & 61 & \multicolumn{3}{|c|}{ Total } \\
\hline
\end{tabular}

Table 2. Describe assess levels of computers physical Parts

\begin{tabular}{|l|l|l|l|l|l|}
\hline $\begin{array}{l}\text { Relative } \\
\text { importance }\end{array}$ & Rate & $\begin{array}{l}\text { Standard } \\
\text { deviation }\end{array}$ & $\begin{array}{l}\text { Arithmetic } \\
\text { mean }\end{array}$ & Paragraph & $\begin{array}{l}\text { Paragraph } \\
\text { number }\end{array}$ \\
\hline $\mathbf{1}$ & $\begin{array}{l}\text { The hospital has hardware and } \\
\text { software that facilitate } \\
\text { operations of beneficiary } \\
\text { within and outside }\end{array}$ & $\mathbf{4 , 2 1 3 1}$ & $\mathbf{0 , 7 0 9 8 1}$ & $\mathbf{1}$ & High \\
\hline $\mathbf{2}$ & $\begin{array}{l}\text { There is widespread use of } \\
\text { computers in hospital, } \\
\text { especially in field of } \\
\text { management }\end{array}$ & $\mathbf{4 , 0 6 5 6}$ & $\mathbf{0 , 8 5 3 7 9}$ & $\mathbf{2}$ & High \\
\hline $\mathbf{3}$ & $\begin{array}{l}\text { The hospital have the necessary } \\
\text { equipments of modernization } \\
\text { and developments to carry out } \\
\text { data processing }\end{array}$ & $\mathbf{3 , 9 0 1 6}$ & $\mathbf{0 , 9 2 5 6 5}$ & $\mathbf{3}$ & High \\
\hline $\begin{array}{l}\text { The arithmetic means and standard deviation to } \\
\text { measure computers parts }\end{array}$ & $\mathbf{4 , 0 6 0 1}$ & $\mathbf{0 , 5 6 9 3}$ & High \\
\hline
\end{tabular}


Table 3. Describe and assess the level of databases

\begin{tabular}{|l|l|c|c|c|c|}
\hline $\begin{array}{l}\text { Paragraph } \\
\text { number }\end{array}$ & Paragraph & $\begin{array}{c}\text { Arithmetic } \\
\text { mean }\end{array}$ & $\begin{array}{l}\text { Standard } \\
\text { deviation }\end{array}$ & Rank & $\begin{array}{c}\text { Relative } \\
\text { importance }\end{array}$ \\
\hline $\mathbf{8}$ & $\begin{array}{l}\text { It Can be dealt easily with the hospital software and } \\
\text { hardware }\end{array}$ & $\mathbf{4 , 0 3 2 8}$ & $\mathbf{0 , 8 9 3 8 2}$ & $\mathbf{1}$ & High \\
\hline $\mathbf{5}$ & $\begin{array}{l}\text { The use of hospital information systems has its } \\
\text { significantly effects on accuracy }\end{array}$ & $\mathbf{4 , 0 1 6 4}$ & $\mathbf{0 , 9 9 1 4 9}$ & $\mathbf{2}$ & High \\
\hline $\mathbf{4}$ & $\begin{array}{l}\text { The hospital possess formative software and information } \\
\text { technology tools that helps manage to retrieve } \\
\text { information used needed }\end{array}$ & $\mathbf{3 , 9 6 7 2}$ & $\mathbf{0 , 9 1 2 2 7}$ & $\mathbf{3}$ & High \\
\hline $\mathbf{6}$ & $\begin{array}{l}\text { The hospital is equipped with software's which I can } \\
\text { deal with information more easily }\end{array}$ & $\mathbf{3 , 9 5 0 8}$ & $\mathbf{0 , 9 7 3 4 2}$ & $\mathbf{4}$ & High \\
\hline $\mathbf{9}$ & $\begin{array}{l}\text { The present Information systems used in the hospital } \\
\text { perform its functions to the fullest extent (processing } \\
\text { and storage of data at both level }\end{array}$ & $\mathbf{3 , 9 1 8 0}$ & $\mathbf{0 , 9 8 8 1 8}$ & $\mathbf{5}$ & High \\
\hline $\mathbf{7}$ & $\begin{array}{l}\text { The hospital uses a systems and software fits according } \\
\text { to staff operations }\end{array}$ & $\mathbf{3 , 8 3 6 1}$ & $\mathbf{0 , 9 5 1 8 5}$ & $\mathbf{6}$ & High \\
\hline $\begin{array}{l}\text { Arithmetic } \\
\text { Software }\end{array}$ & mean and standard deviation for the measurement of & $\mathbf{3 , 9 5 3 6}$ & $\mathbf{0 , 5 7 9 0 6}$ & High \\
\hline
\end{tabular}

Table 4. Describe and assess level of databases

\begin{tabular}{|l|l|c|l|l|l|}
\hline $\begin{array}{l}\text { Paragraph } \\
\text { Number }\end{array}$ & Paragraph & $\begin{array}{c}\text { Arithmetic } \\
\text { mean }\end{array}$ & $\begin{array}{l}\text { Standard } \\
\text { deviation }\end{array}$ & Rank & $\begin{array}{l}\text { Relative } \\
\text { importance }\end{array}$ \\
\hline $\mathbf{1 0}$ & Data is entered accurately while doing hospital work & $\mathbf{3 . 9 6 7 2}$ & $\mathbf{1 . 0 3 2 2 7}$ & $\mathbf{2}$ & High \\
\hline $\mathbf{1 2}$ & $\begin{array}{l}\text { Hospital system maintains with develop information } \\
\text { systems to keep up with current development in } \\
\text { information technology }\end{array}$ & $\mathbf{3 . 9 5 0 8}$ & $\mathbf{0 . 8 4 5 1 1}$ & $\mathbf{2}$ & High \\
\hline $\mathbf{1 1}$ & $\begin{array}{l}\text { Hospital Deals with the resources on a data service } \\
\text { end-user }\end{array}$ & $\mathbf{3 , 8 1 9 7}$ & $\mathbf{0 , 9 0 3 8 5}$ & $\mathbf{3}$ & High \\
\hline $\begin{array}{l}\text { Arithmetic mean and standard deviation for the measurement of } \\
\text { Software }\end{array}$ & $\mathbf{3 , 9 1 2 6}$ & $\mathbf{0 , 6 8 8 2 7}$ & & High \\
\hline
\end{tabular}

Table 5. Local and National Networks

\begin{tabular}{|l|l|c|c|c|c|}
\hline $\begin{array}{l}\text { Paragraph } \\
\text { number }\end{array}$ & Paragraph & $\begin{array}{c}\text { Arithmetic } \\
\text { mean }\end{array}$ & $\begin{array}{c}\text { Standard } \\
\text { deviation }\end{array}$ & Rank & $\begin{array}{c}\text { Relative } \\
\text { importance }\end{array}$ \\
\hline $\mathbf{1 4}$ & $\begin{array}{l}\text { Internet Provides to staff and administrative } \\
\text { leaders many benefits in areas of jurisdiction }\end{array}$ & $\mathbf{4 . 3 7 7 0}$ & $\mathbf{8 1 9 8 4}$ & $\mathbf{1}$ & High \\
\hline $\mathbf{1 6}$ & $\begin{array}{l}\text { The Internet allows me to know the latest } \\
\text { developments in the area of jurisdiction }\end{array}$ & $\mathbf{4 . 1 6 3 9}$ & $\mathbf{1 . 0 8 2 9 0}$ & $\mathbf{2}$ & High \\
\hline $\mathbf{1 8}$ & $\begin{array}{l}\text { There are sharing of inputs \& outputs with other } \\
\text { systems, that lee's of building relationships with } \\
\text { other external environment }\end{array}$ & $\mathbf{4 . 0 3 2 8}$ & $\mathbf{1 . 1 1 0 0 6}$ & $\mathbf{3}$ & High \\
\hline $\mathbf{1 7}$ & $\begin{array}{l}\text { There is post in the data \& information \& } \\
\text { resources between departments at different } \\
\text { administrative levels of the hospital }\end{array}$ & $\mathbf{3 . 9 5 0 8}$ & $\mathbf{. 9 3 8 5 5}$ & $\mathbf{4}$ & High \\
\hline $\mathbf{1 5}$ & $\begin{array}{l}\text { using of Internet on There is an ongoing basis at } \\
\text { hospital }\end{array}$ & $\mathbf{3 . 9 1 8 0}$ & $\mathbf{9 5 3 8 5}$ & $\mathbf{5}$ & High \\
\hline $\mathbf{1 3}$ & $\begin{array}{l}\text { There is a potential growing since of knowledge } \\
\text { while dealing with internet net work }\end{array}$ & $\mathbf{3 . 8 0 3 3}$ & $\mathbf{1 . 2 0 8 5 8}$ & $\mathbf{6}$ & High \\
\hline $\mathbf{1 9}$ & $\begin{array}{l}\text { The Hospital uses latest means of communication } \\
\text { \& networks to transfer data both within \& outside }\end{array}$ & $\mathbf{3 . 7 8 6 9}$ & $\mathbf{1 . 0 8 1 8 9}$ & $\mathbf{7}$ & High \\
\hline $\begin{array}{l}\text { Arithmetic } \\
\text { measurement of Software }\end{array}$ & $\mathbf{4 . 0 0 4 7}$ & $\mathbf{0 . 6 3 4 0 5}$ & & High \\
\hline
\end{tabular}


Table 6. Level of Management control

\begin{tabular}{|c|c|c|c|c|c|}
\hline $\begin{array}{l}\text { Paragraph } \\
\text { number }\end{array}$ & Paragraph & $\begin{array}{l}\text { Arithmetic } \\
\text { mean }\end{array}$ & $\begin{array}{l}\text { Standard } \\
\text { deviation }\end{array}$ & Rank & $\begin{array}{c}\text { Relative } \\
\text { importance }\end{array}$ \\
\hline 31 & $\begin{array}{l}\text { It reflects the regulatory process of hospital the } \\
\text { factual information on working progress }\end{array}$ & 4.0984 & .83076 & 1 & High \\
\hline 20 & $\begin{array}{l}\text { Control Contributes to the regulatory hospital } \\
\text { process to detect deviations efficiently and } \\
\text { effectively }\end{array}$ & 4.0492 & 1.05556 & 2 & High \\
\hline 33 & $\begin{array}{l}\text { The hospital has Available \&clear benchmarks } \\
\text { to monitor Administrative process }\end{array}$ & 3.9836 & .93971 & 3 & High \\
\hline 21 & $\begin{array}{l}\text { The Compilers of control system have } \\
\text { appropriate experience \& qualifications }\end{array}$ & 3.9672 & .94811 & 4 & High \\
\hline 32 & $\begin{array}{l}\text { The control process results\& feedback would } \\
\text { modify plans\& developed of the hospital }\end{array}$ & 3.9508 & .92062 & 5 & High \\
\hline 28 & $\begin{array}{l}\text { The control process have many contributes for } \\
\text { avoiding future error may occur }\end{array}$ & 3.9344 & .98097 & 6 & High \\
\hline 34 & $\begin{array}{l}\text { The control process is characterized as a } \\
\text { preventive measures rather than curative }\end{array}$ & 3.8852 & 1.01814 & 7 & High \\
\hline 22 & $\begin{array}{l}\text { The control process in Hospital is based on } \\
\text { basis of Objective standards }\end{array}$ & 3.8197 & .95757 & 8 & High \\
\hline 23 & $\begin{array}{l}\text { There are diversity in using surveillance tools \& } \\
\text { techniques }\end{array}$ & 3.8033 & .90957 & 9 & High \\
\hline 27 & $\begin{array}{l}\text { The hospital Control system is characterized by } \\
\text { its ability to adapt to changing circumstances }\end{array}$ & 3.7705 & .97286 & 10 & High \\
\hline 21 & $\begin{array}{l}\text { The control process is Characterized by } \\
\text { process of Economics }\end{array}$ & 3.7705 & .98984 & 11 & High \\
\hline 29 & $\begin{array}{l}\text { The control procedures is characterized as ease } \\
\& \text { clarity }\end{array}$ & 3.7541 & 1.10538 & 12 & High \\
\hline 24 & $\begin{array}{l}\text { The control process, protects workers from } \\
\text { abuse by other superiors authority }\end{array}$ & 3.7377 & .98152 & 13 & High \\
\hline 36 & $\begin{array}{l}\text { The control process respond to process of } \\
\text { changes that occur within hospital }\end{array}$ & 3.7213 & 1.06663 & 14 & High \\
\hline 35 & $\begin{array}{l}\text { The control process assist the staff to improve } \\
\text { their performance }\end{array}$ & 3.6885 & 1.13345 & 15 & High \\
\hline 26 & $\begin{array}{l}\text { The control process are comprehensive } \\
\text { oversight in the hospital }\end{array}$ & 3.6557 & 1.01465 & 16 & High \\
\hline 30 & $\begin{array}{l}\text { The control is conducting training courses for } \\
\text { those in charge of the oversight process }\end{array}$ & 3.6393 & 1.08063 & 17 & High \\
\hline \multicolumn{2}{|c|}{$\begin{array}{l}\text { Arithmetic mean and standard deviation for the } \\
\text { measurement of Software }\end{array}$} & 3.8370 & 0.54618 & & High \\
\hline
\end{tabular}


Table 7. Simple regression analysis of the impact of each independent variable (Sub-D) to find management control

\begin{tabular}{|c|c|c|c|c|c|c|c|c|}
\hline \multicolumn{4}{|c|}{ Regression coefficient } & \multirow{2}{*}{$\mathrm{Sig}^{* *}$} & \multirow{2}{*}{$\begin{array}{l}\text { F } \\
\text { Calculated }\end{array}$} & \multirow{2}{*}{$\begin{array}{l}\mathrm{R} 2 \\
\text { Coefficient of } \\
\text { determination }\end{array}$} & \multirow{2}{*}{$\begin{array}{l}\mathrm{R} \\
\text { Correlation } \\
\text { coefficient }\end{array}$} & \multirow{2}{*}{ Hypothesis } \\
\hline $\begin{array}{l}\mathrm{T} \\
\text { Calculated }\end{array}$ & $\begin{array}{l}\text { Standard } \\
\text { error }\end{array}$ & $\beta$ & $\begin{array}{l}\text { Variable } \\
\text { Independent }\end{array}$ & & & & & \\
\hline 6.266 & .097 & .606 & $\begin{array}{l}\text { Main parts } \\
\text { of a } \\
\text { computer }\end{array}$ & .000 & 39.269 & .400 & .632 & First \\
\hline 7.400 & .088 & .654 & Software & .000 & 54.759 & .481 & .694 & Second \\
\hline 5.293 & .085 & .450 & Databases & .000 & 28.011 & .322 & .567 & Third \\
\hline 7.408 & .081 & .598 & $\begin{array}{l}\text { local \& } \\
\text { National } \\
\text { Networks }\end{array}$ & .000 & 54.886 & .482 & .694 & Forth \\
\hline
\end{tabular}

** The effect is statistically significant at the significance level $(\operatorname{Sig} \leq 0.05=\alpha)$

Table 8. Test results for regression analysis (On impact of progressive components in information systems at administrative control)

\begin{tabular}{|c|c|c|c|c|c|c|c|c|c|c|}
\hline \multicolumn{5}{|c|}{ Regression coefficients } & \multirow{2}{*}{$\begin{array}{l}\text { Sig** } \\
\text { Level } \\
\text { Significance }\end{array}$} & \multirow{2}{*}{$\begin{array}{l}\text { DF } \\
\text { Degrees } \\
\text { of } \\
\text { freedom }\end{array}$} & \multirow{2}{*}{$\begin{array}{l}\text { F } \\
\text { Calculated }\end{array}$} & \multirow{2}{*}{$\begin{array}{l}\mathrm{R} 2 \\
\text { Coefficient of } \\
\text { determination }\end{array}$} & \multirow{2}{*}{$\begin{array}{l}\mathrm{R} \\
\text { Correlation } \\
\text { coefficient }\end{array}$} & \multirow[b]{2}{*}{ Form } \\
\hline $\begin{array}{l}\text { Sig** } \\
\text { Significance } \\
\text { Level }\end{array}$ & $\begin{array}{l}\mathrm{t} \\
\text { Calculated }\end{array}$ & $\begin{array}{l}\text { Standard } \\
\text { error }\end{array}$ & $\beta$ & $\begin{array}{l}\text { Independent } \\
\text { variable }\end{array}$ & & & & & & \\
\hline \multirow{3}{*}{.000} & \multirow{3}{*}{9.396} & \multirow{3}{*}{.081} & \multirow{3}{*}{.598} & \multirow{3}{*}{$\begin{array}{l}\text { local and } \\
\text { national } \\
\text { Networks }\end{array}$} & \multirow{3}{*}{.000} & 1 & \multirow{3}{*}{54.886} & \multirow{3}{*}{.482} & \multirow{3}{*}{.694} & \multirow{3}{*}{ First } \\
\hline & & & & & & 59 & & & & \\
\hline & & & & & & 60 & & & & \\
\hline \multirow[b]{2}{*}{.000} & \multirow[b]{2}{*}{3.999} & \multirow{2}{*}{.092} & \multirow{2}{*}{.369} & \multirow{2}{*}{$\begin{array}{l}\text { local and } \\
\text { national } \\
\text { Networks }\end{array}$} & \multirow{3}{*}{.000} & 2 & \multirow{3}{*}{42.335} & \multirow{3}{*}{.593} & \multirow{3}{*}{.770} & \multirow{3}{*}{ Second } \\
\hline & & & & & & 58 & & & & \\
\hline .000 & 3.999 & .101 & .403 & Software & & 60 & & & & \\
\hline .001 & 3.448 & .092 & .316 & $\begin{array}{l}\text { local and } \\
\text { national } \\
\text { Networks }\end{array}$ & \multirow{3}{*}{.000} & 3 & \multirow{3}{*}{32.352} & \multirow{3}{*}{.630} & \multirow{3}{*}{.794} & \multirow{3}{*}{ Third } \\
\hline .007 & 2.794 & .107 & .298 & Software & & 57 & & & & \\
\hline .021 & 2.372 & .100 & .237 & $\begin{array}{l}\text { Material } \\
\text { parts of the } \\
\text { computer }\end{array}$ & & 60 & & & & \\
\hline
\end{tabular}

